\title{
AN INTEGRATED PLANKTONIC (FORAMINIFERA, CALCAREOUS NANNOFOSSILS, DINOCYSTS) BIOSTRATIGRAPHY OF THE PALEOGENE SEDIMENTS FROM THE OIL AND GAS BEARING PROVINCES OF UKRAINE
}

\section{ПЛАНКТОННА БІОСТРАТИГРАФІЯ (ФОРАМІНІФЕРИ, НАНОПЛАНКТОН, ДИНОЦИСТИ) ПАЛЕОГЕНОВИХ ВІДКЛАДІВ НАФТОГАЗНОСНИХ ПРОВІНЦІЙ УКРАЇНИ}

\author{
Aida S. Andreeva-Grygorovych ${ }^{1}$, Ninel V. Maslun ${ }^{1}$, Mykhailo M. Ivanik ${ }^{1}$, Daniel D. Waga ${ }^{2}$, \\ Nataliia M. Zhabina ${ }^{1}$, Svitlana R. Hnylko ${ }^{3}$, Iryna S. Suprun ${ }^{1}$, Ludmyla G. Mintuzova \\ А.С. Андрєєва-Григорович, Н.В. Маслун, М.М. Іванік, Д.Д. Вага, Н.М. Жабіна, С.Р. Гнилко, \\ І.С. Супрун, Л.Г. Мінтузова \\ 1 Institute of Geological Sciences, NAS of Ukraine, 55-b 0. Honchara Str., Kyiv, Ukraine, 01601 (aida_g@ukr.net, ivanik_m@ukr.net, \\ zhabinanatalia@gmail.com, suprun_is@ukr.net) \\ 2 Consulting company "NannoPetroResearch"; Department of Geology, College of Biological and Physical Sciences, University of Nairobi, \\ Kenya (geology@nannopetro.com; wagaden@uonbi.ac.ke) \\ 3 National Academy of Sciences of Ukraine, Institute of Geology and Geochemistry of Combustible Minerals, 3a Naukova Str., Lviv, \\ Ukraine, 79060 (s.hnylko@yahoo.com)
}

In Ukraine, the perspective oil and gas bearing regions are located within the Carpathian-Black Sea segment of the Tethys, and the southern slopes of the East European Platform. We examined the plankton microfossil content from numerous Paleogene samples obtained from outcrop and exploration borehole sections. The interpretation of the large dataset concerning the spatial-temporal distribution of Foraminifera, Calcareous nannofossils and Dinocysts is provided. The characteristics of the stratigraphic distribution of planktonic fossil assemblages in the Paleogene sections, their cyclicity in the formations and the specifics of the zonal subdivision based on the defined correlation levels are given. As a result of an integrated study the biozonal subdivision of Paleogene sediments of Ukraine is substantiated, and an interregional correlation of various facies of the Paleogene sections with the International Stratigraphic Scheme is undertaken.

Keywords: Foraminifera, Calcareous nannofossils, Dinocysts, Zonal Chart, Correlation, Paleogene, Ukraine.

На території України перспективними нафтогазоносними регіонами є Карпато-Чорноморський сегмент Тетиса та Південні схили Східноєвропейської платформи. Авторами особисто досліджено планктонні мікрофосилії з численних розрізів палеогенових відкладів у відслоненнях і розкритих пошуково-розвідувальними та параметричними свердловинами. Опрацьовано значну інформацію щодо просторово-часового розподілу форамініфер, нанопланктону і диноцист в палеогені, на підставі чого встановлено закономірності та особливості стратиграфічної приуроченості планктонних асоціацій викопних решток в палеогенових розрізах, їх циклічність у формаційних комплексах. Викладено специфіку біозонального розподілу за встановленими кореляційними рівнями. В результаті комплексних досліджень обгрунтовано зональний поділ палеогенових відкладів України, виконано міжрегіональну кореляцію різнофаціальних палеогенових розрізів і кореляцію з Міжнародною стратиграфічною шкалою.

Ключові слова: форамініфери, нанопланктон, диноцисти, зональна шкала, кореляція, палеоген, Україна.

\section{INTRODUCTION}

The relation that developed between stratigraphy with paleontology and geology at the start of the XIX century led to the initiation of new research methods, including the biostratigraphic. From the very start the main tasks of biostratigraphy when considered with the requirements of practice were: 1) detailed stratification of the sedimentary strata; 2) tracing the lateral distribution of stratigraphic subdivisions and correlation with other remote sections; 3) Improvement of the International Stratigraphic Scale. The first the biostratigraphic zonation of layers of a section with detailed study of its fossil content with the indication of the first appearance of each species was done by the German paleontologist Albert Oppel in the XIX century. Since then it has become a practice for biostratigraphic research and stimulated the development of paleontology, in particular those studies that are related to the morphology and taxonomy. Complications in correlation of remote multi-facial and diverse sections are largely due to facial variability of sedimentary strata, incompleteness of the sections 
and, consequently, insufficient faunal composition. The solution was found by studying the transition layers that contained fossil remains that were influenced by facial changes. Additionally, paleoenvironmental or ecostratigraphic methods were applied. Palynology method is commonly used to correlate marine and continental facies (A.S. Alekseev (1988), S.V. Meyen (1980), S. Krasilov (1977), Ju.V. Teslenko (1984-2002), O.K. Shogolev (1979-2013), O.P. Fisunenko (1998), V.N. Semenenko (1978-2012), P.F. Gozhyk (1984, 2015, 2015) and others).

The application of the micropalaeontological methods in the practice of biostratigraphic research at the start of the XX-th century was largely stimulated by its wide use during oil and gas exploration, and due to the initiation of drilling projects in the oceans. The developed biozonations that are based on planktonic or pelagic organisms are of great importance for both regional and global correlations, majorly due to the use of microfossils in determining the boundaries of the main stratigraphic units of the International Stratigraphic Scale (ISC). By the end of the XX century, a large dataset concerning the relationship between geological time and stratigraphic divisions was collected from different countries. This topic was further developed by a series of projects supported by large international oil companies, including the "Timescale of the Phanerozoic"; "Cambridge Arctic Shelf Program", etc. The most thorough and interesting international integrated research was "The Geological Time Scale", edited by W.B.Harlend (1982) which includes stratigraphic units that are dated in millions of years, and the main method for determining the boundaries is the fixation of the Global boundary Stratotype Sections and Points (GSSPs). This publication included a new method of chronometric calculation of boundaries based on radioisotope dating, an updated paleomagnetic scale, and all scales were correlated to a single chart of global geological (eustatic fluctuations of sea level, orogenic cycles of tectonics of plates) and biological (appearance and extinction of important groups of organic world) events. The authors emphasize that the scale is not perfect, but gives reasoning for resolving the related issues and identifies the ways of their solution. In recent years, the work on improving the content and quality of the International Chronostratigraphic Chart (ICC) has been continuously under the supervision of the International Commission on Stratigraphy (ICS). The stratotypes of the stages, their volumes and boundaries are constantly reviewed (GTS 2004, 2009, 2012, 2014). A characteristic feature is the complexity of the stratigraphic studies involved, in which, apart from biostratigraphy, such techniques as, sequence stratigraphy, cyclostratigraphy, chemostratigraphy and others are applied), and emphasizes the influence of all geological processes on the stratigraphic structure (Maslun et al., 2015).

In Ukraine, the perspective oil and gas bearing regions are located within the CarpathianBlack Sea segment of the Tethys, and the southern slopes of the East European Platform. Detailed stratification and substantiation of the spatial-temporal relationships of Paleogene formations of the Tethyan and Boreal-Atlantic segments within Ukraine are based on the study of microfossils, namely, Planktonic foraminifera, Benthic Foraminifera (Secreted and Agglutinated), Calcareous nannofossils, Dinoflagellates, Diatoms, Radiolarians, Sponge spicules. Nearly all biostratigraphic charts of the Carpathian, Crimea, North Black Sea and Azov-Black Sea regions are generated based on these microfossil groups. Among them, the Planktonic, Benthic Foraminifera and Calcareous nannofossils are the marker horizon groups that are used for terrigenous-carbonate formations stratifications, while Agglutinated Foraminifera, Dinoflagellates, Sponges spicules, Diatoms, Radiolarians are more useful for terrigenous-siliceous formations biostratigraphy.

The first attempt of detailed biostratigraphy and correlation of Paleogene deposits of Ukraine was performed by the research P.A. Tutkovsky (Tutkovsky, 1887), who initiated the microfaunal analysis based foraminifers and performed correlation. Major contributions in the study of Foraminifera was done by Boyaryntseva N.Ya., Brazhnikova N.Ye., Bugrova E.M., Vasilenko V.P., Venglinsky I.V., Voloshyna G.M., Vyalov O.S., Holubnichaya L.M., Gruzman A.D., Dabagyan N.V., Dain L.G., Digas L.O., Zhelezhyak V.E., Zhabina N.M., Ivanik M.M., KaptarenkoChernousova O.K., Kyrylova T.A., Konenkova I.D., Krayeva E.Ya., Lypnyk O.S., Maslakova N.I., Maslun N.V., Menkes (Tkachuk) M.O., Mintuzova L.G., Morozova V.G., Myatlyuk O.V., Nikitina Yu.P., Pechonkina A.P., Pyshvanova L.S., Ponomarjova L.D., Prosnyakova (Ivanova) L.V., Ryabokon T.S., Savenko N.G., Samoylova R.B., Sobolev G.D., Subbotina N.N., Ulanovska T.A., 
Fursenko A.V., Shvemberger O.N., Shutska K.K., Yartseva M.V. and many others.

The first biozonation scales of Paleogene deposits based on Foraminifer were proposed by O.K. Kaptarenko-Chernousova (KaptarenkoChernousova, 1958), N.N. Subbotina (19391960), V.G. Morozova (1939-1967), Ye.K. loped by W. Bolli (1966), W.H. Blow (1979), W. Berggren et al. (1995) (Wade et al., 2011). We have adopted the biozonal charts for the Crimea-Caucasus region, developed by V.A. Krasheninnikov et al. (1998-2007) (Krasheninnikov, Basov, 2007), V.N. Beniamovski (Benyamovsky, 2001), E.M. Bugrova (Bugrova, 2001), N.V. Maslun, S.R. Hnylko, L.G. Mintuzova (Maslun et al., 2015).

The calcareous nannofossil biozonations were first introduced by Wade, Mohler, Hay, (1967) based on the drilling data from the shelfal area near Florida (USA). Later, E. Martini (Martini, 1971) published the first standard nannofossil biozonation scales of the Paleogene, Neogene and Quaternary deposits developed on the basis of data obtained from the study of European epicontinental stratotype sections. In 1973 and 1980 two biozonation scales related to the study of D. Bukry (Bukry, 1973; Okada \& Bukry, 1980) were compiled from the materials of the Deep Sea Drilling Project (currently Ocean Drilling Project). The first calcareous nannofossil biostratigraphy of the Paleogene sediments of the Bakhchisaray section of Crimea was developed by A.S. Andreeva-Grigorovich (1973). A detailed research of the stratigraphic distribution of calcareous nannofossils from the Paleogene sections of the Carpathian region and other southern areas of the former USSR was USSR was undertaken in framework for the development of a regional stratigraphic scale of the Paleogene deposits for the southern regions of Ukraine (A.S. Andreeva-Grigorovich, N.G. Muzylöv, I.P. Tabachnikova (Andreeva-Grigorovich et al., 1991).

The first Dinocyst biozonal subdivision of the Paleogene in Western Europe is related to publications by Costa, Downie (1976), Chataneaneuf, Gruas-Cavagnetto (1978). Later, more detailed biozonation scales that were calibrated with the nannofossil zones of E. Martini $(1970,1971)$ and planktonic foraminifera Blow (1969), W.A. Berggren (1972) were published. A.S. AndreevaGrigorovich $(1985,1991,1994)$ developed the first Dinocyst biozonal scales for the Paleogene of the Carpathian, Crimean-Caucasus and the Caspian regions of the former Soviet Union. More recently, based on the new results and data, the Dinocyst biozonal scale of the Paleogene sediments of Ukraine has undergone some improvements and refinements (A.S. AndreevaGrigorovich, T.V. Shevchenko, E.S. Oleinik (Andreeva-Grigorovich et al., 2011). These results were correlated with the generalized Paleogene biozonal scale of Luterbacher et al. (2004).

The current Paleogene biostratigraphy of the western, northern and southern regions of Ukraine is based on data from three major microfossil groups (Foraminifera, Dinocysts, Calcareous nannofossils).

\section{METHODS AND MATERIAL}

The most complete sections of Paleocene sediments have been found within the CarpathianBlack Sea region of the Tethys. In Northern Ukraine (East European platform segment) the epicontinental basins of Paleo-Atlantic "Boreal" Ocean once developed. This area differs by its stratigraphic nature from the southern one by the presence of incomplete sections, and by the mainly non-carbonate type of sedimentation However, the evidence of paleogeographic connections between the Tethys and Paleo-Atlantic (boreal) basins can be clearly observed here. We have examined the presence of microfossils from numerous Paleogene sections from outcrop and borehole material of the Carpathian, Southern (North Black Sea region, Crimea, Kerch peninsula, Azov and Black Sea basin) and Northern (Ukrainian Shield, Dnieper-Donets Depression) regions of Ukraine.

In the Carpathian-Black Sea region of Tethys, the most complete sections of Paleocene deposits are established. Within North Ukraine (the territory of the East European platform) the epicontinental basins of Paleoathlantic "boreal" ocean were developed. In the stratigraphic structure of this region, which differs from the southern one by incomplete sections, due to the mainly non-carbonate sedimentation, the paleogeographic connections between the Tethys and Paleo-Atlantic (boreal) basins can be clearly traced. The authors of this paper examined the plankton microfossil content from numerous Paleogene samples obtained from outcrop and exploration borehole sections in Ukrainian Carpathians, Southern Ukraine (Black Sea Coast, Crimea, Kerch peninsula, Azov and Black Sea basins) and North Ukraine (Ukrainian Shield, the Dnieper-Donets Basin). 
Bio-, litho-, cyclo- and seismostratigraphic, paleoecological, facies, sedimentological, structural-tectonic methods that are components of the basin event stratigraphy were applied for detailed stratigraphic subdivision of polycyclic, multi-facial formations that are typical for the Paleogene deposits of Ukraine. The development of biostratigraphic zonal standards is the framework upon which the stratigraphic subdivision of these formations is possible.

The datum levels and the position of the boundaries of diverse stratigraphic units were determined based on the stratigraphical distribution of orthostatigraphic and parataxonomic groups of fauna and flora with consideration of various processes and events. The interpretation of the large dataset concerning the spatial-temporal distribution of Foraminifera, Calcareous nannofossils and Dinocysts in the Paleogene anabled to establish the quality and characteristics of the stratigraphic relations of the planktonic assemblages in the Paleocene-EoceneOligocene sections, as well as their cyclicity within the formations. The specifics of the zonal subdivision based on the established correlation levels are provided. As a result of these integrated studies, the zonal division of the Paleogene deposits of Ukraine (Figure 1) was substantiated. In addition to the main criteria parameters, other factors, such as, the tectonic structure and dynamics within the Backarc-Riftogenic subsidense regime of the Crimean and Black Sea rifts during the Cretaceous-Cenozoic age were considered in developing a detailed local Paleogene stratigraphy of the western and southern regions of Ukraine.

\section{PLANKTONIC MICROFOSIL BIOSTRATIGRAPHY OF PALEOGENE SEDIMENTS OF UKRAINE} In the Ukrainian Carpathians, the Planktonic foraminifera appear in the following sequence of zones: Paleocene - Parvularugoglobigerina eugubina, Globoconusa daubjergensis, Morozovella angulata s.l., Globanomalina pseudomenardii; Acarinina acarinata; Eocene - Morozovella subbotinae, Morozovella aragonensis, Acarinina bullbrook, Acarinina rotundimarginata, Hantkenina alabamensis, Globigerinateka tropicalis, Subbotina corpulenta; Oligocene Subbotina officinalis, S. vialovi, Turboritalia liverovskae, Cassigerina chipolensis, Globigerina ampliapertura, strata with Turborotalia opima opima - Globigerina ciperoensis. The benthic secreted and agglutinated foraminifera also provide high resolution biozonation and correlation of polyfacial formations (Gruzman, 1983; Hnylko, Hnylko, 2016; Ivanik, Maslun, 1977; Justification of stratigraphic (ed. V.Ya. Didkovskiy), 1975; Maslun et al., 2015; Myatlyuk, 1970; Vyalov O.S. et al., 1988). Analysis and interpretation of data on the foraminifera biostratigraphy of Ukrainian were perfomed by N.V. Maslun, M.M. Ivanik, S.R. Hnylko, L.G. Mintuzova and N.M. Zhabina. A complete sequence of Standard nannofossil zones ranging from NP1 to NP25 were established by A.S. Andreeva-Grigorovich (A.S. AndreevaGrigorovich et al., 2004), A.M. Romaniv (Romaniv, 1991), D.D. Waga (Waga, 2007), I.S. Suprun (Suprun, 2017)) and all dinocysts zones of the Paleogene from DP1 to DP14 have been established (Andreeva-Grigorovich et al., 2011).

Paleogene sediments of the southern regions of Ukraine, including the Azov-Black Sea area are characterized by all foraminifera zones of the Crimean-Caucasian region biozonal scale. These are: Paleocene - Parvularugoglobigerina eugubina, Eoglobigerina taurica, Globoconusa daubjergensis - Parasubbotina pseudobulloides, Praemurica inconstans, Morozovella angulata, Morozovella conicotruncata, Igorina dianensis, Acarinina subsphaerica, Acarinina acarinata; Eocene - Morozovella subbotinae, Morozovella aragonensis, Acarinina bullbrooki, Acarinina rotundimarginata, Globigerinatheka subconglobata, Subbotina turcmenica, Globigerinateka tropicalis; Oligocene includes Subbotina officinalis, S. vialovi, S. tapuriensis, Turboritalia liverovskae, Cassigerina chipolensis, Globigerina ampliapertura, strata with Turborotalia opima opima - Globigerina ciperoensis are recognized ciperoensis (Benyamovsky, 2001; Bugrova, 2001; Gozhyk et al., 2015; Gozhyk, 2011; Gozhyk et al., 2006; Krasheninnikov, Basov, 2007; Kraeva, Yartseva, 1973; Krayeva, Maslun, 1984; Maslun et al., 1989; Mintuzova, 2008; Ryabokon, 2014; Subbotina, 1960; Zhabina, Mintuzova, 2000). According to the calcareous nannofossil biostratigraphy the Paleogene of South Ukraine is assigned to the range of from NP1 to NP23 zones (A.S. Andreeva-Grigorovich, M.G. Muzylöv, I.P. Tabachnikova (Andreeva-Grigorovich et al., 1991), S.A. Lyuljeva (Zernetsky, Lyulyeva, 1990), E.M. Bogdanovich, D.D. Waga (Waga et al., 2010), etc.). The Dinocyst zonation from DP1 to DP14 have also been established (A.S. AndreevaGrigorovich, T.V. Shevchenko, Ye.S. Oleinik, 
N.A Savitskaya, O.B. Stotland, A.I. Yakovleva, etc. (Andreeva-Grigorovich et al., 2011)).

In the North Ukraine, the Paleocene includes Planktonic foraminifera zones Globoconusa daubjergensis - Parasubbotina pseudobulloides, Praemurica inconstans, Morozovella angulata, Acarinina tadjikistanensis - Igorina djanensis Globorotalia pseudomenardii, beds with Acarinina kiewensis. From the Eocene, benthic foraminifera assemblages with Cibicides lectus (Danian), Cibicides favorabilis (Selandian Thanetian) have been distinguished (O.K. Kaptarenko-Chernousova, M.V. Yartseva, E.Ya. Krajeva, N.V. Maslun, T.S. Ryabokon', I.D. Konenkova, M.M. Ivanik). Generally, the Eocene sediments of this region do not contain Planktonic Foraminifera, and biozonation is performed based on benthic foraminifera that demonstrate wide correlation possibilities within the southern regions of Ukraine and the adjacent territories of Russia (Voronezh anticlise, Volga and Baltic regions). Exceptional importence here has the publication of O.K. KaptanenkoChernousova (Kaptarenko-Chernousova, 1958) that considers the detail foraminifera biozonation of the Kiev formation. According to the calcareous nannofossil biostratigraphy, the range of nannozones NP1- NP8 and NP15-NP20 were distinguished (A.S. Andreeva-Grigorovich, S.A. L'ulyeva, G.P. Kalinichenko, N.A. Savitskaya, Ye.M. Solyanik, D.D. Waga). The Paleocene Dinocyst assemblages (Areoligera senonensis L.-Carp., A. coronata (0. Wetz.), Senoniasphaera inornata Drugg., Glaphyrocysta perforata Hultberg, Thalassiphora pelagica Morg., Spiniferites ramosus (Ehr.) and others, beds with Cordosphaeridium gracile, subzone DP7a (upper part of Ypresian), DP7b (Lutetian), DP9, DP10, DP11 (Priabonian), DP13 (Early Oligocene), Chiropteridium partispinatum (Late Oligocene) have all been recognized (A.S. AndreevaGrigorovich , T.V. Shevchenko).

The established zones (including beds, typical assemblages) enabled the correlation of the local regional stratigraphic subdivisions of the Paleogene sediments in each of the studied region.

Paleocene. In the Carpathian region, the Paleocene is represented by the upper part of the Rusychan regional stage and the lower part of the Karpiynian regional stage. This includes the upper member of the Stryi Formation, Yamna Formation and their age contemporaneous on the southern slope (the lower parts of the Metovska and Belovezhska Formations). Complete sections that comprise all Paleocene Planktonic foraminifera, Dinocysts and Calcareous nannofossil biozones are established.

Paleocene deposits in the Northern Ukraine regions are represented by the Psolskian and Merlinskian substages of the Sumian regional stage. In the Southern Ukraine region, the Paleocene sediments are considered in the range of the Bilokamian (Danian - Lower Selandian stages) and Kachian (Selandian - Thanetian stages) regional stages. The sediments of the Bilokamian stage usually ovelay those of the Maastrichtian with a sign of an unconformity. The sections of the North-Western Shelf of the Black Sea, Kerch Peninsula and the Indolo-Kuban Trench contain all Paleocene Planktonic foraminifera, Calcareous nannofossil and Dinocysts biozones.

\section{Paleocene Foraminifera biostratigraphy:}

Parvularogoglobigerina eugubina zone (Luterbacher, Premoli Silva, 1964) is derived from the lowest part of the Danian stage. It includes the stratigraphic distribution of Parvularugo - globigerina eugubina. The zone is defined in the Ukrainian Carpathians in the lower parts of Metovska and $\mathrm{Bi}$ owez formations, in the South Ukraine - within the lower parts of the Bilokamian regional stage of the Kerch Peninsula and South-Eastern Crimea. It corresponds to the subzone P1a subzone of the International Stratigraphic Chart (2009). It also corresponds to the contemporaneous zones established in Western Turkmenistan, Caribbean, tropical and subtropical regions of the Pacific Ocean, SouthEastern Crimea and Eastern Mediterranean.

Eoglobigerina taurica zone (Morozova, 1960) - Lower Danian stage; corresponds to the stratigraphic interval of Eoglobigerina taurica. It is defined at the bottom of the Bilokamian regional stage in Crimea, on the Black Sea shelf and in the Northern Black Sea coast. This zone corresponds to the PP1 zone of the Crimean Caucasus region biozonation scale.

Globoconusa daubjergensis - Parasubbotina pseudobulloides zone (V.P. Alimarina, 1961) Middle Danian stage, corresponds to the presence interval of zonal species Globoconusa daubjergensis and Parasubbotina pseudobulloides. It is determined in the sediments of the Psolskian regional stage of Northern Ukraine, as 
well as at the bottom of Bilokamian regional stage of the Tarkhankut area of Crimea, Kerch peninsula and the Black Sea shelf. It correlates with the Parasubbotina pseudobulloides Subbotina trilocylonoides zones of the Caucasus and the Caribbean regions; Parasubbotina pseudobulloides-subbotin triloculinoides zones of Armenia; Globoconusa daubjergensis of the Tarkhankut area of the Steppe Crimea, Azerbaijan, Western Turkmenistan and Eastern Mediterranean.

Praemurica inconstans zone (N.M. Subbotina, 1953; Globigerina inconstans) - Upper Danian. The zone corresponds to the Praemurica inconstans mass distribution interval. It is defined in the middle part of the Bilokamian Formation in Crimea, Kerch Peninsula and the Northern Black Sea region. It corresponds to the PP3 zone of the Crimean-Caucasian region biozonation, and to the analogue zones defined in Caucasus, Turkmenistan, Kazakhstan, Armenia, Caribbean Region, Eastern Mediterranean and the Atlantic boreal region.

Morozovella angulata zone (Khalilov, 1948; Globorotalia angulata) - Lower Selandian. The zone corresponds to the acme of the zonal specie Morozovella angulata. The zone is identified at the top part of the section of the Bilokamian regional stage of Crimea, Kerch peninsula, Northern Black Sea coast region and Black Sea shelf. The zone correlates with the analogue zone of Caucasus, Georgia, Armenia, Azerbaijan, Kazakhstan, Turkmenistan and the Caribbean region. It is correlated with the PP4 zone of the detailed Crimean-Caucasian region biozonation and subzone P3a of the Bergren et al, 1995 Planktonic Foraminifera zonation. This determines its stratigraphic position and enables its geological dating as Selandian.

In the Ukrainian Carpathians, the Morozovella angulata zone of Lower Selandian correlates to the Morozovella angulata and Morozovella conicotruncata zones of Southern Ukraine. Here, this zone zone is defined as an interval between (FO) Morozovella angulata and FO Globanomalina pseudomenardii. It is defined in the lower part of the Karpiynian regional stage, and the Metovska Formation of the Carpathian region. Typical species of this zone were found in the Merlin regional stage of the Northern Ukraine region. This zone correlates with the P3 zone of the International Stratigraphic Chart.

Morozovella conicotruncata zone (N.M. Sub- botina, 1953; = Globorotalia conicotruncata) Lower Selandian. This zone corresponds to the acme of the zonal specie Morozovella conicotruncata. It is defined in the topmost part of the Bilokamian regional stage of Crimea, Kerch Peninsula, Northern Black Sea Coast region. It corresponds to the PP5 zone of the CrimeanCaucasian biozonation scale. Contenporaneous biozones were discovered in Caucasus, Kazakhstan, Georgia and Turkmenistan.

Globanomalina pseudomenardii zone Upper Selandian. This zone corresponds to the distribution range of Globanomalina pseudomenardii. It is defined in the lower part of the Karpiynian regional stage, in the Metovska and Bilowezhska formations of the Ukrainian Carpathians. The zone corresponds to the interval of Igorina dianensis and Acarinina subsphaerica of the South Ukraine region, and to the P4 zone of the International Stratigraphic chart.

Igorina djanensis zone (Shutskaya, 1962) Mid Selandian. Locally defined in the lower part at the Kachian regional stage of the foothills area of the Crimea Mountains. The zone corresponds to the PP6 zone of the of the Crimean-Caucasus biozonal scale.

Acarinina subsphaerica zone (K.K. Shut S kaya, 1956) - Lower Thanetian. The zone corresponds to the interval of the acme of zonal specie Acarinina subsphaerica and the FO of Globanomalina elongata. zone (Shutskaya, 1962) - Mid Selandian. Locally defined in the lower part at the Kachian regional stage of the foothills area of the Crimea Mountains. The zone corresponds to the PP6 zone of the of the Crimean-Caucasus biozonal scaleat the lowermost part of the Kachian regional stage of Crimea, Kerch peninsula, Northern Black Sea coast area and Black Sea shelf. It corresponds to the PP7 zone of the Crimean-Caucasian biozonal scale. Analogue zones were established in Western Crimea, Caucasus, western part of Central Asia, Azerbaijan and Turkmenistan.

Acarinina acarinata zone (K.K. Shutskaya, 1956) - Upper Thanetian. The zone is determined in the Bilowiezhska and Sushmanian Formations (lower part of the Karpiynian regional stage) of the Ukrainain Carpathians, upper part of the Kachian regional stages of Crimea, Kerch peninsula, Northern Black Sea coast area. The zone correlates to the PP8 zone of the CrimeanCaucasian biozonal scale. It is analogue to the zones established in the Crimean region, 
Caucasus, west of the Central Asia, Georgia, Azerbaijan and Kazakhstan.

\section{Paleocene calcareous nannofossil biostratigraphy:}

NP1- Biantholithus sparsus zone (Mohler \& Hay in Hay et al. (1967), emend Martini (1970), emend Perch-Nielson (1979) - Danian. The zone is defined as the interval from (FO) Biantholithus sparsus to FO Cruciplacolithus tenuis. Common species are: Markalius inversus, Braarudosphaera discula, Coccolithus cavus, Thoracosphaera operculata, Prinsius dimorphosus, $P$. martini. The zone includes reworked Cretaceous species. The zone is defined in the Ukrainian Carpathians region within in the lower part of the Upper Stryi Formation, upper part of the Urdinska Formation and the basal part of the Metovska Formation, as well as in the Bakhchisaray stratotype section of Crimea and the southern part of the Eastern European Platform.

NP2 - Cruciplacolithus tenuis zone (Mohler \& Hay; Hay in Hay et al, 1967), Emend. Martini (1970) - Lower Danian. The zone is determined as the interval between FO Cruciplacolithus tenuis to FO Chiasmolithus danicus. Common species of the zone are: Cruciplacolithus tenuis, Markalius inversus, Braarudosphaera discula, Coccolithus cavus, Thoracosphaera operculata, Prinsius martini, Biantholithus sparsus. The zone is established in the Carpathian Mountains - in the lower part of the Upper Stryi subformation, upper part of the Stryi Formation; in the Bakhchisaray district of Crimea - in the lower part of the Bilokamian formation.

NP3 - Chiasmolithus danicus zone (Martini, 1970) - Danian. The zone is defined as the interval from FO Chiasmolithus danicus to FO Ellipsolithus macellus. Common species: Chiasmolithus danicus, Coccolithus cavus, Cruciplacolithus tenuis, Toweius craticulus, Prinsius martinii, P. dimorphosus, Chiasmolithus consuetus, Neochiastozygus concinnus, Coccolithus eopelagicus, Coccolithus sp., Zygodiscus sigmoides, Biantholithus sparsus. The zone was established in the Carpathian Mountains - within the lower part of the Upper Stryi subformation, Bitkiv beds, upper part of the Berezansk formation, as well as in the Sumy Formation of the Dnipro-Donets Depression; Bilokamian regional stage of the Black Sea shelf and Bakhchisaray area of Mountaneous Crimea.

NP4 - Ellipsolithus macellus zone (Martini, 1970a) - Upper Danian - Lower Selandian.
Interval from FO Ellipsolithus macellus to FO Fasciculithus tympaniformis. Common species: Chiasmolithus danicus, Coccolithus cavus, Ericsoni subpertusa, Cruciplacolithus tenuis, Prinsius dimorphosus, P. martinii, Zygodiscus sigmoides, $Z$. adamas. The zone was established in the several sections of the Carpathian Mountains - within the uppermost part of the Upper Stryi subformation and the lower part of the Yaremche Formation; in the Biktiv beds, as well as in the Makartin formation of the Luzaniv stratotype region. In the Bilokamian formation of the Northwestern Black Sea shelf, the upper subzone Sphenolithus primus (NP4b) of the Quillevere et al (2004) zonation has been established.

NP5 - Fascikulus tympaniformis zone (Mohler \& Hay in Hay et al., 1967) - Middle Selandian. The zone is the interval from the FO of the Fasciculithus tympaniformis to FO Heliolithus kleinpellii. Common species: Fasciculithus tympaniformis, F.involutus, Ellipsolithus macellus, Chiasmolithus danicus, Coccolithus cavus, Ericsoni subpertusa, Cruciplacolithus tenuis, Prinsius dimorphosus, P.martinii, Zygodiscus sigmoides, Z.adamas. The zone is defined in the Yaremche horizon, in the Gnilets and Metovska Formations of the Ukrainian Carpathians, in the Suma Formation of the Dnipro-Donets Depression, in the Bilokamian and Kachian Formations of the Black Sea shelf; Kachian and Inkermanian regional stages of the Bakhchisaray section of Crimea; in the Inkermanian regional stage of the Black Sea basin.

NP6 - Heliolithus kleinpelli zone (Mohler \& Hay in Hay et al., 1967) - Upper Selandian Lower Thanetian. The zone is defined as the interval from FO Heliolithus kleinpellii.to FO Discoaster gemmeus or D. mohleri. Common species: Heliolithus kleinpellii, Neochiastozygus distentus, N.chiatus, Toweius pertusus. The zone is established in the Yaremche Formation and in the lower part of the Yamna Formation, and in the Metovska and Sushmanetsk Formations of the Ukrainian Carpathians, in the Kachian regional stage of the Black Sea shelf, Bakhchisaray regional stage of the Crimea, Western Black Sea coast and the Sivash area of Crimea.

NP7 - Discoaster gemmeus zone (Hay, 1964 and Mohler \& Hay in Hay et al., 1967) - Lower Thanetian. Common species: Coccolithus pelagicus, Discoaster gemmeus, D. cf. mohler, Ericsonia subpertusa, Heliolithus kleinpellii, Fasciculithus excutum, F. tympaniformis. It is established 
in the upper part of the Biktiv beds of the Carpathian sections in the Kachian regional stage of the Bakhchisaray section of Crimea, the Northern Black Sea coast.

NP8 - Heliolithus ridelii zone (Bramlette \& Sullivan, 1961 and Perch-Nilsen, 1972) - Upper Thanetian. Interval from FO Heliolithus ridelii to FO Discoaster multiradiatus. Common species: Heliolithus kleinpellii, H. riedelii, Dioscoaster mohler, Neochiastozygus concinnus, N. chiatus, Toweius pertusus, T. cf. eminen, Fasciculitus involutus, Sphenolithus primus. The zone is established in the middle part of the Yamnenska and in the Metovska Formations of the Ukrainian Carpathians, in the Kachian regional stage of the Black Sea shelf, Bakhchisaray section of Crimea, in the Paleocene of the Western and Eastern Black Sea coast areas.

NP9 - Discoaster multiradiatus zone (Bramlette et Sullivan, 1961) - Upper Thanetian. Common species: Discoaster multiradiatus, Dioscoaster mohleri, D. nobilis Martini, Neochiastozygus concinnus, N. chiatus, Toweius pertusus, T. cf. eminen, Sphenolithus primus. The assemblage of the zone was identified in the upper part of the Yamnenska Formation of the Ukrainian Carpathians and Bakhchisaray regional stage of the Northern Black Sea Coast and Mountaineous Crimea

Paleocene Dinocyst biostratigraphy:

DP1 Carpatella cornuta s. str. zone - Lower Danian. The zone is defined as the interval from FO Carpatella cornuta to FO Alterbidinium circulum. The zone is subdivided into two subzones DP1a and DP1b. The zone was established in the lower part of the Upper Stryi subformation of the Carpathian Mountains (with two subzones), in the upper part of the Psolskian and lower part of the Merlin subregional stages, Sumy regional stage (combined assemblage); in the Bilokamian regional stage of the Mountaineous Crimea. It correlates with nannozones NP2 - NP4 (lower part)

DP1a Carpatella cornuta s. str. subzone Lower Danian. It is defined as the interval from FO to LO Carpatella cornuta, the upper limit - FO Cerodinium striatum. Common species of the subzone are Spinidinium densispinatum, Senoniasphaera inornata, Spiniferites septatus, S. cornutus, S. ramosus, Palaeoperidinium pyrophorum, Achomosphaera alcicornum, A. ramulifera, Cribroperidinium wetzelii, Palaeocystodinium benjamins, Cerodinium diebelii, Deflandrea danica. The subzone correlates with NP1 nannozone.

DP1b Cerodinium striatum subzoneDanian. It is identified as the interval from FO Cerodinium striatum to FO Alterbidinium circuIum. The subzone is characterized by the wide development of the index species, and by the assemblage presented by Xenicodinium Iubricum, $X$. reticulatum, Spiniferites cryptovesiculatus, Fibrocysta oval, Microdinium dentatum, Senegalinium obscurum.

DP2 Cerodinium speciosum s. I zone Selandian - Thanetian. It is defined as the interval from FO Alterbidinium circulum to FO Apectodinium homomorphum. The zone is characterized by the acme of Cerodinium speciosum. The zone is subdivided into three subzones DP2a, DP2b, DP2s and is correlated to the NP4 (upper part) - NP8 nannozones.

DP2a Cerodinium speciosum subzone Selandian. The subzone is defined as the interval from FO Alterbidinium circulum to FO Alisocysta margarita. Common species: Palaeoperidinium pyrophorum, Spiniferites septatus, Alterbidinium circulum, Leberidocysta chlamydata, Eisenackia crassitabulata, Cerodinium speciosum, C. prutense, C. leptodermatum. The subzone is established at the topmost part of the Stryi and Yaremche Formations of the Ukrainian Carpathians, in the Sumy regional stage of the Northern Ukrainian region, in the lower part of the Kachian regional stage of the South Ukraine region.

DP2b Alisocysta margarita subzone - Lower Thanetian. The subzone is defined as the interval from FO Alisocysta margarita to FO Rottnestia borussica. The assemblage resembles the previous one, with the exception that the specie Palaeoperidinium pyrophorum appears in the upper part of the subzone. The assemblage is characterized by the presence of Deflandrea delineata, Paleocystodinium golzowense, Spiniferites cornutus, Lejeunecysta hyalina, Leberidocysta chlamydata, Alterbia minor. The subzone was established in the sections of the Carpathian region within the Yaremche layers, Yamna Formation.

DP2c Rottnestia borussica subzone Danian. It is defined as the interval from FO Rottnestia borussica to FO Apectodinium homomorphum. The assemblage includes all earlier mentioned species, including the zonal, with the exception of Alisocysta margarita. The subzone is 
established in the lower part of the Yamna Formation of the Ukrainian Carpathians.

DP3 Apectodinium homomorphum zone Upper Thanetian. The zone is defined as the interval from FO Apectodinium homomorphum to FO Wetzeliella meckelfeldensis. The assemblage of the zone is characterized by the appearance of Deflandrea denticulata, D. oebisfeldensis, D. carpatica, D. dissoluta, Apectodinium parvum, Cerodinium prutense, C. leptodermum, Lanternosphaeridium lanosum, Alisocysta circumtabulata, Glaphyrocysta ordinata. The zone was established in the upper part of the Yamna Formation of the Ukrainian Carpathians, upper part of the Kachian regional stage of the South Ukrainian region. The zone is correlated with the NP9 nannozone.

The upper limit of the Paleocene in most of the studied sections is truncated by erosion or characterized by a sharp facies change in hardly accesible sections. Therefore, the upper part of the Apectodi - nium homomorphum zone and the Lower Eocene Wetzeliella astra has not yet been detected.

Eocene. In the stratotype Carpathian region, the Karpiynian regional stage of the Eocene is represented by the Manyavska, Vygodska, and Bystricka Formations and their correlative analogues in various structural and facial zones of the Outer and Inner Carpathians. The carbonate facies include all Eocene planktonic foraminifera zones of the Crimean-Caucasian scale. However, the typical assemblages of these zones in the Carpathians differ somewhat in their systematic composition reflecting other paleoecological conditions.

In the North Ukraine region, the Eocene deposits are represented by the regional stages: Kaniv (Lower Eocene), Buchak and Kiev (Middle Eocene) and Obukhiv Formations (Upper Eocene). For these regions, the Eocene is characterized by incomplete sections, unconformities and the absence of outcrops. As a rule, these sediments are barren on planktonic fossil content.

The Eocene deposits in the South Ukraine region is represented by the following regional stages - Bakhchisaray (Lower Eocene), Simferopolian (Lower-Middle Eocene), Novopavlian, Kuma (Middle Eocene), Almian (Upper Eocene). Complete sections of these sediments are encountered from drilling data. They contain all Eocene Planktonic foraminifera, Calcareous nannofossil and dinocysts biozonations of the Crimean-Caucasian scale.
Eocene Foraminifera biostratigraphy:

Morozovella subbotinae zone (V.G. Morozova, 1946; Globorotalia subbotina) - Lower Ypresian. The zone corresponds to the distribution interval of Morozovella subbotinae or (at the top) and Morozovella marginodentata. The area is defined in the Metovska Formation of the Ukrainian Carpathians, lower part of the Bakhchisaray regional stage of Mountaneous Crimea, Kerch peninsula, Northern Black Sea coast and the Black Sea shelf. It corresponds to the PP9 zone of the Crimean-Caucasian scale. Analogue corresponding zones were established in Caucasus region, Georgia, Caribbean region, Armenia, Azerbaijan, Kazakhstan, Turkmenistan and in the boreal region of the Atlantic Ocean.

Morozovella aragonensis zone (D.M. Khalilov, 1948; Globorotalia aragonensis). Upper Ypresian. The zone is defined as the interval between FO Morozovella aragonensis to FO Acarinina bullbrooki. The zone was defined in the Metovska Formation of the Ukrainian Carpathians, in the upper part of the Bakhchisaray regional stage of Crimea, Kerch Peninsula, Northern Black Sea Coast and the Black Sea shelf. Analogue corresponding zones were established in the Caucasus, Georgia, Caribbean region, Armenia, Azerbaijan, Kazakhstan, Turkmenistan and boreal region of the Atlantic Ocean. The zone corresponds to the PP10 zone of the CrimeanCaucasian scale.

Acarinina bullbrooki zone (N.N. Subbotina, 1939; Globorotalia crassaformis) - Upper Ypresian -Lower Lutetian. The zone id defined as the acme interval of Acarinina bullbrooki. The zone was established in Metovska and Bilovezka Formations of the Ukrainian Carpathians, top part of the Simferopol regional stage in Crimea, Kerch peninsula, Northern Black Sea coast and the Black Sea shelf. It corresponds to the PP11 zone of the Crimean-Caucasian scale. It correlates with analogue zone of Crimea, the Caucasus, Georgia, Armenia, Kazakhstan and Turkmenistan.

Acarinina rotundimarginata zone (N.N. Subbotina, 1953) - Lower Lutetian. The zone is defined by the acme of Acarinina rotundimarginata. The zone is established in the Metovska, Bilovezhska, Bystrzycka, Parodchinska Formations of the Ukrainian Carpathians, lower part of the Novopavlivsk regional stage in Crimea, Kerch Peninsula, Northern Black Sea and Black Sea shelf. The common species of this zone are wide- 
spread in the sediments of the Buchak regional stage of the North Ukraine region. The zone corresponds to the PP12 zone of the CrimeanCaucasian scale. It correlates with analogue zones of Crimea, Caucasus, Georgia, Armenia, Azerbaijan, Eastern Mediterranean, Kazakhstan.

Globigerinatheka subconglobata zone (Ye.K. Shutskaya, 1970; Globigerinoides subconglobata) - Upper Lutetian. The zone is defined as an acme interval of Globigerinatheka subconglobata. The zone is established at the top of the Novopavlivsk stage of Southern Ukraine. It corresponds to G. subconglobata and G. index subzones of PP13 zone of the Crimean-Caucasian scale. It is correlated with analogue zones of the Caucasus, Azerbaijan, Turkmenistan.

Subbotina turcmenica zone (Khalilov, 1948) corresponds to the distribution interval of Subbotina turcmenica. The zone is defined in the Kuma regional stage of Crimea and Northern Black Sea region. In the Ukrainian Carpathians the Subbotina turcmenica zone corresponds to the Hantkenina alabamensis zone of Metovska Formation. Typical species of this zone are common in the sediments of the Kiev regional stage of the North Ukrainain region. The zone corresponds to PP13 zone of the scale of the CrimeanCaucasian region.

Globigerinatea tropicalis zone (N.N. Subbotina, 1939; Globigerinoides conglobatus) Lower Priabonian. The zone is defined as the distribution interval of Globigerinateka tropicalis. The zone is established in the upper part of the Karpiynian regional stage of most structural and facial units of the Ukrainian Carpathians within the Bystricka, Popilska, Vyshkivska, Metovska Formations, in Almian regional stage of Crimea. In the studied sections, the zone is determined together with the NP19-20 nannozones. It corresponds to the PP15 zone of the CrimeanCaucasian scale and correlated with analogue zones of Caucasus, Kazakhstan and Turkmenistan.

Subbotina corpulenta zone (N.N. Subbotina, 1939 = Large Globigerina subzone) - Upper Priabonian. The zone corresponds to the distribution interval of Subbotina corpulenta. The zone is established in the regionally distributed "Globigerina marl" horizon of the Carpathian region. It completes the section of the Karpiynian regional stage (upper parts of the Bystricka, Popelska, Vyshkivska, Parodchinska, Metovska Formations). In the studied sections, the zone is established together with the NP19-21 nannozones. The zone corresponds to the PP13b subzone of the biozonation scale of the CrimeanCaucasian region.

In the Southern region the Globigerinateka tropicalis and Subbotina corpulenta zones of the Carpathian region correspond to the Globigerinateka tropicalis s. I. zone. It was derived from the upper part of the Almian regional stage of Crimea, Kerch peninsula, Northern Black Sea coast and the Black Sea shelf.

Eocene Calcareous nannofossil biostratigraphy:

NP10 - Tribrachiatus contortus zone (Hay, 1964; Bukry, 1973) - Lower Ypresian. Interval from FO Tribrachiathus bramlettei or Discoaster diastypus and Tribrachiathus contortus (Okada and Bukry, 1980; CP9) to (LO) Tribrachiathus contortus (LO). Common zone species are: Ellipsolitus macellus, Tribrachiathus bramlettei, T. contortus, Discoaster mediosus, Markalius inversus and others. The topmost part of this nannozone is established in the Sushmanetska Formation of the Trans-Carpathian region.

NP11 - Discoaster binodosus zone (Mohler \& Hay in Hay et al., 1967) - Lower Ypresian. Common zone species: Chiasmolithus bidens, C. californicus, C. consuetus, Coccolithus eopelagicus, Cruciplacolithus staurion, Discoaster barbadiensis, D. binodosus, D. multiradiatus, Ericsonia subpertusa, Zygrhablithus bijugatus, etc. The zone was established within the Pasichnyanska and Strichavska Formations of the Carpathians.

NP12 - Tribrachiathus orthostylus zone (Bronnimann \& Stradner, 1969; Bukry, 1973) Middle Ypresian. Common zone species: Chiasmolithus bidens, $C$ californicus, $C$. consuetus, Coccolithus eopelagicus, Cruciplacolithus staurion, Discoaster lodoensis, D. barbadiensis, D. binodosus, D. multiradiatus, Ericsonia subpertusa, Zygrhablithus bijugatus, Sphenolithus radians. The zone is defined within the upper part of the Maniavska Formation of the Ukrainian Carpathians, in the sediments of the Bakhchisaray regional stage of the Mountaineous Crimea, Kerch Peninsula and the Northern Black Sea Coast.

NP13 - Discoaster lodoensis zone (Bronnimann \& Stradner, 1969; Bukry, 1973) - Upper Ypresian. Common species: Chiasmolithus californicus, Ch. solidus, Ch. bidens, Ch. expansus, Coccolithus eopelagicus, Cyclococcolithus formosus (Ericsonia formosa), Discoaster mediosus, 
$D$. barbadiensis, D. nobilis, D. distinctus, D. germanicus, D. binodosus, D. lodoensis, D. elegans, Ericsonia subpertusa, Zygrhablithus bijugatus, Sphenolithus radians. The assemblage of the nannozone is established in the lower part of the Zlinska Formation of the Ukrainian Carpathians, Bakhchisaray area of Crimea, in the Upper Paleocene - Lower Eocene section of Nasypkoi bay of the Eastern Crimea (I.P. Tabachnikova).

NP14 - Discoaster sublodoensis zone (Hay, 1964; Bukry, 1973) - Lower Lutetian. Common species: Coccolithus eopelagicus, Ericsonia formosa, Chiasmolithus solitus, Diascoaster barbadiensis, D. nonaradiatus, D. sublodoensis, Ericsoni subpertusa, Zyghrablithus bilugatus, Rhabdosphaera inflata, Rhabdolithus gladius, Sphenolithus radians. The assemblage of the zone is defined in the sediments of the Pasichnynska Formation of the Carpathian region, Crimea and the Northern Black Sea coast.

NP15 - Nannotetrina fulgens zone (Hay in Hay et al., 1967, emend, Martini, 1970; Bukry, 1973) - Lutetian. The nannozone is defined as an interval from FO Nannotetrina fulgens to LO Rhabdosphaera inflata and/or to LO Nannotetrina species. Common species of the nannozone are: Nannotetrina fulgens, $N$. pappii, N. cristata, Helicosphaera seminulum, Coccolithus eopelagicus, Ericsonia formosa, Chiasmolithus solitus, Ch. grandis, Ch. modestus, Ch. gigas, Discoaster barbadiens, D. monaradiatus, D. binodosus hirundinus, D. deflandrei, D. sublodoensis, Lanternithus minutus, Ericsonia subpertusa, Zyghrablithus bijugatus, Rhabdosphaera inflata, Rhabdolithus gladius, Sphenolithus radians. The nannozone is derived from the upper part of the Pasichnianska Formation and the lower part of the Bystricka Formation, the Bukovinian beds of the Ukrainian Carpathians; from thick grey sands and clays of the Buchak and the lower part of the Kyiv regional stages of the Kryviy Rih iron ore basin; from the lower part of the Halep'ian Formation of the Kyiv Dnipro region (N.A. Savitskaya (1996)); from the Kuma regional stage of the Bakhchisaray district of Crimea (A.S. Andreeva-Grigorovich et al., 1991), in the Novopavlivsk regional stage of the Steppe Crimea and the Kerch Peninsula; from the Kuberlinian and Keresta regional stages of the Black Sea coastal areaof the Black Sea coastal area.

NP16 - Discoaster tani nodifer zone (Hay et al., 1967, emend, Martini, 1970) - Upper
Lutetian - Lower Bartonian. The nannozone is defined as the interval from FO Reticulofenestra umbilica and Discoaster bifax, and/ or to LO Nannotetrina species to LO Chiasmolithus solitus and Discoaster bifax. Common species of the nannozone: Reticulofenestra umbilica, $R$. dictyoda, Discoaster bifax, Helicosphaera seminulum, H. compacta, Coccolithus eopelagicus, Ericsonia formosa, Chiasmolithus solitus, Ch. grandis, Ch. nitidus, Discoaster barbadiensis, D. tani nodifer, $D$. binodosus hirundinus, D. deflandrei, D. germanicus, Lanternithus minutus, Ericsonia fenestrata, Zyghrablithus bilugatus, Rhabdosphaera inflata, Blackites gladius. The nannozone is established in the lower part of the Bystricka Formation of the Ukrainian Carpathians; Kuma regional stage of Crimea and the Kerch Peninsula (N.A. Savitskaya (1996), A.S. Andreeva-Grigorovich et al., 1991). In the North Ukraine region this nannozone is designated as the subzone of Discoaster bifax zone, Reticulofenestra umbilica (CP13) zone from the sediments of the Kiev Formation of the Kryvyi Rih iron ore basin (A.S. Andreeva-Grigorovich et al. (2003)); established in Eocene sediments developed on the north-eastern side of the Dnipro-Donets Depression; in the upper part of the Halep'yan and lower parts of the Staykinsk Formations of the Kyiv Dnieper region (N.A. Savitskaya (1996)).

NP17 Discoaster saipanensis zone (Martini, 1970) - Upper Bartonian. The zone is defined as the interval from LO Chiasmolithus solitus and Discoaster bifax to FO Chiasmolithus oamaruensis and LO Chiasmolithus grandis. Common species of the nannozone are: Reticulofenestra umbilica, R. dictyoda, Discoaster bifax, Helicosphaera seminulum, H. compacta, Coccolithus eopelagicus, Ericsonia formosa, Chiasmolithus grandis, Ch. nitidus, Discoaster barbadiensis, $D$. saipanensis, $D$. binodosus hirundinus, D. deflandrei, D. germanicus, Corannulus germanicus, Lanternithus minutus, Ericsonia fenestrata, Zyghrablithus bilugatus, Cribrocentrum reticulatum, Blackites gladius, $B$. spinosus, Orthozygus aureus, Pontosphaera multipora, Transversopontis pulcher, Sphenolithus radians. The nannozone is defined in the middle part of the Bystricka Formation; in the lower part of the Turitska Formation; in the transitional layer of the Vitwicka Formation to the Popilska Formation of the Ukrainian Carpathians; in the Kuma Formation of the Bakhchisaray district of Crimea, Steppe Crimea and the Kerch peninsula and the 
Northern Black Sea coast (A.S. AndreevaGrigorovich, E.M. Bogdanovich (1979)); in the Kyiv Formation (Dang-Dyk Nga (1973), Shumenko and Dang Dyk Nga (1973), A.S. An dreeva-Grigorovich); in the Staykin and Obukhiv Formations of the Kyiv Dnipro region and in the lower part of the Mandrikovka beds of s.l. (N.A. Savitskaya (1996)). This nannozone correlates to the analogue zone of the North Caucasus.

NP18 Chiasmolithus oamaruensis zone (Martini, 1970) - Lower Priabonian. The nannozone is defined as the interval from FO Chiasmolithus oamaruensis to FO Isthmolithus recurvus. The zonal specie Chiasmolithus grandis disappears at the lower part of the nannozone. Common species: Reticulofenestra umbilica, R. dictyoda, Discoaster tani nodifer, Helicosphaera seminulum, H. compacta, Coccolithus eopelagicus, Ericsonia formosa, Chiasmolithus oamaruensis, Discoaster barbadiensis, D. saipanensis, D. binodosus, D. deflandrei, D. germanicus, Corannulus germanicus, Lanternithus minutus, Ericsonia fenestrata, Zyghrablithus bilugatus, Cribrocentrum reticulatum, Blackites gladius, B. spinosus, Orthozygus aureus, Pontosphaera multipora, Transversopontis pulcher, Neococcolithus dubius. The nannozone is established in the middle part of the Bystricka Formation of the Ukrainian Carpathians; in the Alminian Formation of the Bakhchisaray area of Crimea (N.G. Muzylöv, I.P.Tabachnikova); in the Kuma regional stage of the Steppe Crimea (A.V. Prosnyakova (1969)) and the North Black Sea. The Discoaster barbadiensis S.I. zone of the A.S. Andreeva-Grigorovich et al. biozonation (1991) is established in the Bakhchisaray district of Crimea.

NP19 Isthmolithus recurvus zone (Hay, Mohler \& Wade, 1966, emend, Martini, 1970) Priabonian. The nannozone is defined as the interval from the FO Isthmolithus recurvus to the FO Sphenolithus pseudoradians. Common species of the nannozone include: Coccolithus eopelagicus, Ericsonia formosa, E. subdisticha, Cyclicargolithus floridanus, Discoaster barbadiensis, D. binodosus, D. deflandrei, D. saipanensis, D. tani nodifer, Isthmolithus recurvus, Helicopontosphaera compacta, Reticulofenestra bisecta, R. dictyoda, R. umbilica, Sphenolithus predistentus. The nannozone is established in the upper part of the Bystrytska, Zlinska, Turitska Formations, and in the Vyshkivska Formation of the Ukrainian Carpathians; in the Almian regional stage of the Bakhchisaray district of Crimea and on the Black Sea shelf (Golitsyn high). It correlates with the contemporaneous zone of the Northern ForeCaucasus that is part of a combined Discoaster barbadiensis s.l. of Okada \& Bukry (1980) and A.S. Andreeva-Grigorovich et al. (1991) biozonation (Waga, 2004, 2007).

NP20 Sphenolithus pseudoradians zone (Martini, 1970) - Priabonian. The nannozone corresponds to the interval from FO Sphenolithus pseudoradians to LO Discoaster barbadiensis, D. saipanensis. Common species: Ericsonia formosa, Cyclicargolithus floridanus, Discoaster barbadiensis, D. binodosus, D. saipanensis, D. tani nodifer, Isthmolithus recurvus, Reticulofenestra bisecta, R. dictyoda, R. umbilica, Sphenolithus predientus, S. pseudoradians. The nannozone is established in the upper part of the Bystricka Formation of the Ukrainian Carpathians; in the Almian regional stage of the Bakhchisaray district of Crimea (in the combined Discoaster barbadiensis s.l. zone of Okada and Bukry (1980), and A.S. Andreeva-Grigorovich et al (1991) zonation. The zone correlates with the contemporaneous zone from sections of the Northern Caucasus and Scythian plate (Waga, 2004, 2007).

NP21 Ericsonia subdisticha zone (Roth in Hay et al., 1967, emend, Martini, 1970) - Upper Priabonian - Lower Rupelian. The nannozone is defined as the interval from (LO) Discoaster barbadiensis and $D$. saipanensis to the LO Ericsonia formosa. Common species of the nannozone: Chiasmolithus oamaruensis, Coccolithus eopelagicus, Ericsonia subdisticha, E. formosa, Cycligargolithus floridanus, Cribrocentrum (Reticulofenestra) reticulatum, Discoaster tani nodifer, Isthmolithus recurvus, Lanternitus minutus, Reticulofenestra bisecta, R. dictyoda, R. hesslandii, R. umbilica, Sphenolithus predistentus, Transversopontis pulcher. The nannozone is established in the Sheshor horizon, the Popilska Formation, the upper part of the Turicka, Bystricka, and the Vyshkivska Formations of the Ukrainian Carpathians; in the Alminsky Formation of the Bakhchisaray district of Crimea. This nannozone correlates with contemporaneous zones of the Northern Fore-Caucasus (Waga, 2004; 2007).

Eocene Dinocyst biostratigraphy:

DP4 Wetzeliella mezkelfeldensis zone Lower Ypresian. The zone is identified as the interval from FO Wetzeliella meckelfeldensis to 
FO Dracodinium simile. Common species: Deflandrea phosphoritica, D. oebisfeldensis, D. carpatica, Wetzeliella astra, Cerodinium prutense, Glaphyrocysta ordinata, Cordosphaeridium gracile, Areoligera senonensis, Spiniferites ramosus, etc. The zone is defined in Manyavska and Vytwiczka Formations of the Ukrainian Carpathians, and also in the Bakhchisarayska Formation of Crimea. This zone correlates with the upper part of the NP10 nannozone.

DP5 Dracodinium simile zone - Lower Ypresian. The zone is identified as the interval from FO Dracodinium simile to FO Dracodinium varielongitudum. The characteristic species of the zone are: Areoligera senonensis, Achomosphaera ramulifera, Cerodinium striatum, Dracodinium solidum, Deflandrea phosphoritica, D. oebisfeldensis, Areoligera coronata, Cordosphaeridium gracile, Homotryblium tenuispinosum, Palaeocystodinium golzowense, Thalassiphora pelagica, Spiniferite ramus, Wetzeliella meckelfeldensis, W. Iunaris. This zone is defined in Manyavska and Vytwiczka Formations of the Ukrainian Carpathians, and also in the Bakhchisarayska Formation of Crimea. The zone is correlated with the NP11 nannozone.

DP6 Dracodinium varielongitudum zone Lower Ypresian. The zone is identified as the interval from FO Dracodinium varielongitudum to FO Charlesdowniea coleothrypta. The assemblage of this zone includes most species of the previous zone, as well as Impagidinium maculatum, Diphyes colligerum, Nematosphaeropsis reticulensis, Operculodinium divergens, Samlandia chlamydophora, and others. This zone is defined within the Manyasvska Formation of the Ukrainian Carpathians and in Bakhchisarayska Formation of Crimea. The zone corresponds to the lower part of the NP12 nannozone.

DP7 Charlesdowniea coleothrypta s.I. zone Upper Ypresian - Lutetian. The zone is identified as the interval from FO Charlesdowniea coleothrypta to FO Enneadocysta multicornuta. This zone is defined in Vygodska and Pasichnyanska Formations of the Ukrainian Carpathians, and also, in the Bakhchisarayska, Simferopolska, Novopavlivska Formations of Crimea. The zone is correlated to the NP12 NP16 (lower part) nannozones. The zone is subdivided into two sub-zones - DP7a and DP7b.

DP7a Charlesdowniea coleothrypta s. str. subzone - Upper Ypresian - Lower Lutetian. The subzone is identified as the interval from FO
Charlesdowniea coleothrypta to FO Enneadocysta arcuata. Common species include: Apectodinium paniculatum, Cordosphaeridium cracenospinosum, C. exilimurum, Deflandrea oebisfeldensis, Dracodinium condylos, Homotryblium tenuispinosum, Charlesdowniea tenuivirgula, Rhombodinium glabrum, Wetzeliella Iunaris, Spiniferites septatus. Single Achomosphaera alcicornu, Cleistosphaeridium insolitum, Cordosphaeridium inodes, C. divergens, Fibrocysta radiata, Hystrichokolpoma granulatum, Kisselovia insolens, Wetzeliella articulata, W. hampdenensis and others have been observed in the upper part of this subzone.

DP7b Enneadocysta arcuata subzone Upper Ypresian-Lutetian. The subzone is identified as the interval from FO Enneadocysta arcuata to FO Enneadocysta multicornuta. The assemblage of the subzone is presented by: Areoligera tauloma, Areosphaeridium diktyoplokum, Heteraulacacysta leptalea, Corrudinium incomcompatium, Wetzeliella articulata, W. oval, Charlesdowniea coleothrypta, Ch. fasciata, Rottnestia borussica and others.

DP8 Enneadocysta multicornuta zone (corresponds to the Wetzeliella articulata zone of the A.S. Andreeva-Grigorovich et al. (1991) zonation - Upper Lutetian - Lower Bartonian. The zone is identified as the interval from FO Enneadocysta multicornuta to FO Rhombodinium draco. The assemblage includes numerous Wetzeliella articulata; other species, like Areosphaeridium diktyoplokum, Enneadocyst arcuata, Hystrichokolpoma salacium, Microdinium reticulatum, M. singulare, Cannosphaeropsis reticulensis, Heteraulacacysta porosa, Deflandrea phosphoritica are also present. A significant number of species of Rhombodinium pustulosum, green algae (Tasmanites spp., Crassosphaera spp., Noremia minor), acritarchs of Paucilobimorpha triradiata, P. granulata, Schepelevia scita were observed in the sections of the Bakhchisaray district of Crimea. This zone is defined in Bystricka Formation of the Ukrainian Carpathians, and also in the Novopavliavska and Kumska Formations of Crimea. The zone corresponds to NP16 (upper part) - NP17 (lower part) nannozones.

DP9 Rhombodinium draco zone (Dracodinium intermedium / Areosphaeridium diktyoplokum zone according to the A.S. AndreevaGrigorovich et al. (1991) zonation - Bartonian. The zone is identified as the interval from FO Rhombodinium draco to FO Rhombodinium poro- 
sum. The assemblage of this zone is presented by: Enneadocysta arcuata, E. multicornuta, Hystrichokolpoma salacium, Microdinium singulare, Dracodinium rhomboideum, Deflandrea spp., Heteraulacacysta leptalea, Cerebrocysta bartoniensis, Phthanoperidinium alectrolophum, P. echinatum, Wetzeliella spp., Palaeocystodinium golzowense, etc. and numerous Areosphaeridium diktyoplokum. This zone is defined in Bystricka Formation of the Ukrainian Carpathians, and also in the Kumska Formation of Crimea. The zone corresponds to the NP17 nannozone (partially).

DP10 Rhombodinium porosum zone - Upper Bartonian. The zone is identified as the interval from FO Rhombodinium porosum to FO Rhombodinium perforatum. The assemblage of the zone contains Cordosphaeridium cantharellum, Phthanoperidinium comatum, Areosphaeridium diktyoplokum, Enneadocysta multicornuta, Hystrichokolpoma salacium, Microdinium singulare, Charlesdowniea clathrata, Deflandrea spp., Rhombodinium draco, Rhombodinium spp., Homotryblium floripes, Glaphyrocysta texta, Wetzeliella spp., etc. This zone is defined in Bystricka Formation of the Ukrainian Carpathians and in Kumska Formation of Crimea. The zone corresponds to the NP17 nannozone (partially).

DP11 Rhombodinium perforatum / Charlesdowniea clathrata angulosa zone Priabonian. The zone is identified as the interval from FO Rhombodinium perforatum to FO Chiropteridium galea. The zone assemblage contains Areosphaeridium diktyoplokum, Enneadocysta multicornuta, Deflandrea spp., Homotryblium floripes, Charlesdowniea clathrata angulosa, Glaphyrocysta texta, Rhombodinium spp., Wetzeliella simplex, W. spinula, W. articulata, Impagidinium disperitis, I. maculatum, Phthanoperidinium eocenicum, P. amoenum, $P$. comatum, and others. In the sections of the Bakhchisaray area of Crimea the zone is characteristized by the massive development of green algae, mainly Tytthodiscus beloglinense, Tasmanites globulus, etc.; in the North Ukraine region this zone is characterized by the massive development of Deflandrea spp. in the lower part of the zone and green algae (Tacmanites concinnus) - in the upper. This zone is defined in Bystricka and Popilska Formations of the Ukrainian Carpathians, and also in the Alminska Formation of Crimea. The zone correlates to NP18 -NP21 (bottom part) nannozones.
Oligocene. Oligocene deposits in the Carpathian region are represented by the Ombronian regional stage and the lower part of the Eggerian, and mainly complete sections of the Menilite and Krosno types. In the Southern regions of Ukraine, the Oligocene deposits are represented by the following regional stages (bottom-top): Planorbellian, Molochanskian (Rupelian), Kerleutian Caucasian - Lower Caucasian subregional stage (Chattian).

\section{Oligocene Foraminifera Biostratigraphy:}

The following planktonic foraminifera zones have been recognized in the Oligocene sections of the Ukrainian Carpathian sections (Ye.V. Mjatlyuk., N.M. Subbotina, N.V. Dabagyan, A.D. Gruzman, M.M. Ivanik, N.V. Maslun (Myatlyuk, 1970; Subbotina, 1960; Gruzman A.D., 1983; Justification of stratigraphic... (Ed. V.Ya. Didkovskiy), 1975; Ivanik, Maslun, 1977; Maslun, 2015): Subbotina officinalis - S. vialovi, Cassigerina chipolensis (Lower Oligocene), Tenuitellinata ciperoensis -T. opima opima (Upper Oligocene).

In the South Ukraine region, three beds with Foraminifera are recognized in the Lower Rupelian sections (Planorbel regional stage): beds with Subbotina officinalis, Globigerina tapuriensis, beds with Globigerina khadumica and Turborotalia cerroazulensis. These sediments include assemblages of NP21 (top part) NP22 nannozones, and dinoflagellates of DP12 and DP13 zones. The Kerleutian regional stage contains the beds with Globigerina ciperoensis, Gl. praubulloides, Subbotina brevispira, while the upper part of the Oligocene (Lower Caucasian regional stage) - Turborotalia obessa, Globigerinoides primordius. The defined levels enable the correlation of this section with the P15-P19 zones of the Berrggren et al. (1995) (Gozhyk et al., 2006; Gozhyk et al., 2015; Subbotina, 1960).

Turborotalia cerroazulensis zone (Berrggren et al. (1995)) - Rupelian. In the biozonal charts for the Crimea-Caucasus region, developed by Krasheninnikov V.A., Basov I.A. (2007), the Subbotina officinalis zone corresponds to the Turborotalia cerroazulensis zone and has been determined in the sections of the Alpine geosynclinal belt and Atlantic. In the Ukrainian Carpathians the Subbotina officinalis - S. vialovi zone is determined at the same level.

Subbotina officinalis - S. vialovi zone Lower Rupelian. The assemblage includes 
Subbotina officinalis, S. vialovi, S. droogeri, Tenuitella munda, T. liverovskae, Tenuitellinata postcretacea, Chiloguembelina cubensis, Pseudohastegerina micra. The zone was established in the Lower Menilite Formation of the Ukrainian Carpathians; in the lower part of the Planorbellian regional stage and the Nikopolska Formation of Crimea and the Northern Black Sea coastal area. These deposits contain Calcareous nannofossils (NP22 and NP23 zones) and Dinocysts (Phthanoperidinium amoenum and Wetzeliella gochtii zones).

Cassigerinella chipolensis zone - Rupelian. The assemblage includes numerous Cassigerinella chipolensis. The zone was found in the upper part of the Lower Menilitic formation, in Verecka and Krosno formations of the Ukrainian Carpathians. The Lower Rupelian sediments of the Molochanskian regional stage of South Ukraine region contain only Globigerina pseudoedita, Gl. praubulloides. Additionally, these deposits contain Calcareous nannofossils (NP23 zone) and Dinocysts (Wetzeliella gochtii zone).

Globigerina ampliapertura zone - Upper Rupelian - Chattian. The assemblage includes numerous Globigerina ampliapertura in association with Globigerina ouachitaensis, Subbotina brevispira, Tenuitellinata angustiumbilicata. The zone was established in the Middle Menilitic and Lower Krosno subformations, Verecka formation of the Ukrainian Carpathians; in Kerleutian regional stage of the South Ukraine. These deposits contain Calcareous nannofossils (NP23, NP24, NP25 zones) and Dinocysts (Wetzeliella gochtii zone) (Gozhyk et al., 2011; Gozhyk et al., 2015).

Tenuitellinata ciperoensis-T. opima opima zone - Chattian. The zone was established in the Middle Menilite Formation, and the upper part of the Lower Krosno formation of the Ukrainian Carpathians. It is recognized in the Northern Black Sea, Crimea, Azov-Black Sea offshore sections, and in the stratotype and parastatrotype sections of the North Caucasus. The following assemblage is defined within the UpperKerleutska subformation: Globigerina ciperoensis, Gl. praubuloides, Subbotina brevispira, Brizalina missippiensis, Sphaeroidina variabilis. The biostratigraphy enables to correlate this part of the Oligocene section with the P18 - P22 Foraminifera zones of the Berggren et al. (1995) zonation.

\section{Oligocene Calcareous nannofossil biostratigraphy:}

NP22 - Helicosphaera retuculata zone (Bramlette \& Wilcoxon, 1967, emend, Martini, 1970) - Lower Rupelian. The zone is identified as the interval from (LO) Ericsonia formosa to LO Reticulofenestra umbilica. The common species of the zone are: Coccolithus eopelagicus, Ericsonia subdisticha, Cyclicargolithus floridanus, Isthmolithus recurvus, Helicosphaera compacta, $H$. reticulata, Reticulofenestra bisecta, $R$. dictyoda, R. umbilica, and Sphenolithus predistentus. The zone is established in the Rybnicky horizon, in the upper part of the Sheshorsky horizon and in the Dusinska Formation of the Ukrainian Carpathians; in the upper part of the Planorbellian regional stage and the Nikopolska Formation of Crimea and the Northern Black Sea.

NP23-Spenolithus predistentus zone (Bramlette \& Wilcoxon, 1967, emend, Martini, 1970) - Rupelian. Common species of the assemblage are: Reticulofenestra ornata, $R$. locker, R. bisecta, Transversopontis fibula, T. zigzag, Cyclicargolithus floridanus. This complex is defined in the carbonate interlayers among the hornfels in the Verecka Formation and the Lower Menilite subformation of the Ukrainian Carpathians. These sediments with endemic species coresponds to beds with ostracoda in the South regions. In Crimea, Northern Black Sea Region, the upper part of NP23 zone contains Sphenolitus distentus, S. moriformis, S. predistentus, Pontosphaera multipora, Zygrhablithus bijugatus, Braarudosphaera bigelowii.

NP24-Spenolithus distentus zone (Bramlette \& Wilcoxon, 1967) - Upper Rupelian - Lower Chattian. The characteristic species of the assemblage are: Reticulofenestra lockeri, R. bisecta, Cyclicargolitthus floridanus, Helicosphaera oblique, H. bramlettei, Pontosphaera multipora, Sphenolitus distentus, S. moriformis, S. ciperoensis, Zygrhablithus bijugatus, Braarudosphaera bigelowii. The assemblage is established in the carbonate layers of the Lower Menelite and the lower part of the Middle Menilite, in the Lower Krosno subformations of the Ukrainian Carpathians.

NP25-Spenolithus ciperoensis zone (Bramlette \& Wilcoxon, 1967, emend, Martini, 1970) - Chattian. Typical species of the zone assemblage are: Reticulofenestra bisecta, Cyclicargolitthus floridanus, $C$. abisectus Helicosphaera oblique, $H$. bramlettei, $H$. recta, 
Pontosphaera multipora, Sphenolitus moriformis, S. ciperoensis, Discoaster deflandrei, Zygrhablithus bijugatus, Braarudosphaera bigelowii, Triquetrorhabdulus carinatus. The assemblage is established in the Middle-Upper Menelite subformations, in the upper part of the Lower Krosno subformation, and in the Malovyzhenska Formation of the Ukrainian Carpathians.

Oligocene Dinocyst biostratigraphy:

DP12 Phthanoperidinium amoenum / Wetzeliella symmetrica zone - Lower Rupelian. The zone is characterized by the mass presence of Phthanoperidinim amoenum, as well as the FO Wetzeliella symmetrica that occurs slightly above the lower boundary of the zone. In some sections of the Carpathians - the zone is characterized by the appearance of Deflandrea spinulosa and Lentinia serrata. The most common species are: Deflandrea phosphoritica, Pentadinium laticinctum, Charlesdowniea clathrata angulosa, Rhombodinium draco, $R$. Iongimanum, Wetzeliella articulata, Ascostomocystis potane, Glaphyrocysta texta, Homotryblium spp., Cribroperidinium tenuitabulatum. The zone is characterized by the large number of green algae - mainly Tasmanites spp., Tyttodiscus spp., Crassosphaera spp. etc. The zone is established in the upper part of the Sheshorsky horizon, Popilska and Bystricka Formations of the Ukrainian Carpathians; in the lower part of the Mezhigorska Formation of the North Ukraine region, in the lower part of the Planorbellian regional stage in Crimea and the Northern Black Sea coast. This zone corresponds to the top of the NP21 nannozone.

DP13 Wetzeliella gochtii zone - Lower Rupelian. The zone is defined as the interval from FO Wetzeliella gochtii to the frequent presence of Chirophteridium galea. Common species of the zone include Deflandrea spp., Rhombodinium drag, Rh. longimanum, Lentinia serrata, Apteodinium spiridoides, Dapsilidinium simplex, Homotryblium spp., Pentadinium laticinctum, Membranophoridium aspinatum. It is established in the hornfel layers, lower part of the Menilite and Veretska Formations of the Ukrainian Carpathians, in the upper part of the Mezhigorian regional stage of the North Ukraine region; in the Molochanskian regional stage of Crimea and Northern Black Sea. The zone corresponds to the NP22 and NP23 (lower part) nannozones.
DP14 Chiropteridium galea zone - Upper Rupelian and Chattian. The zone corresponds to acme interval of Chiropteridium galea (= Chiropteridium partispinatum). The lower part of the zone contains Apteodinium spiridoides; Charlesdowniea marginata and LO Rhombodinium draco occur in the middle part of zone. The upper part of the zone in the Northern Black Sea region contains the acme of Deflandrea. The upper boundary of the zone is determined by the LO zonal species and Membranophoridium aspinatum. In different regions of Ukraine beds with distinctive species of this zone are distinguished (AndreevaGrigorovich (1991, 1994); Shevchenko (2002)). The LO Deflandrea phosphoritica was observed in the lower part of the Lower Miocene (AndreevaGrigorovich (1991, 2004); Andreeva-Grigorovich et al. (1993)). Typical species of the zone are Distatodinium biffii, Charlesdowniea marginata, Wetzeliella symmetrica, Chiropteridium lobospinosum, Membranophoridium aspinatum, Nomotryblium spp., Cordosphaeridium cantharellum, Dapsilidinium simplex, Thalassiphora reticulata, Ascostomacystis potane, Deflandrea spinulosa, $D$. elegantica, and others. The zone is determined in the Lower - Middle Menelite, and Lower Krosno subformations of the Carpathians. The zone corresponds to the NP23 (upper part) NP25 nannozones.

\section{CONCLUSIONS}

Thus, the Carpathian-Black Sea segment of Tethys contains a complete sequence of Planktonic foraminifera, Calcareous nannofossils, and Dinocysts biozonations. The biostratigraphy results indicate to the existence of normal marine conditions in the sedimentary basin throughout the Paleogene. In the Boreal-Atlantic province (Northern regions of Ukraine), the Planktonic foraminifera and Calcareous nannofossil biozonations encounter some complications. In such areas, the microfossils are presented by the Dinocysts, Secreted and agglutinated benthic Foraminifera, Radiolarians and Sponge spicules that have larger applications. The integrated biostratigraphy of the studied sections enabled to perform a interregional correlation of various-facial Paleogene sediments across Ukraine with the regional stratigraphic units of the adjacent regions, and the stage subdivisions of the International Stratigraphic Scale. 


\section{ACKNOWLEDGEMENTS}

Work was carried out to a large extent within the framework of the project on development of system methodology of the constructing of variety of stratigraphic models of oil-producing MezoCenozoic sediments. The authors wish to thank for significant cooperation that improved the manuscript content the academic P.F. Gozhyk, candidate of geological - mineralogical scienses G.V. Kliushyna (Institute of Geological Sciences,

\section{REFERENCES}

Andreeva-Grigorovich A.S., Muzylov N.G., Tabachnikova I.P., 1991. Biozonation of the Paleogene of the south of the USSR based on nannofossils. Zonal stratigraphy of the Phanerozoic of the USSR. Moscow: Nedra, , pp. 134-135 (in Russian).

Andreeva-Grigorovich A.S., Zaporozhets N.I., Shevchenko T.V., et al., 2011. Atlas of Paleogene dinocysts of the Ukraine and adjacent countries, Kyiv: Naukova Dumka, 224 p. (in Russian).

Andreyeva-Grigorovich A.S., Ivanik M.M., Maslun N.V. et al., 2004. Paleogene regional stages of Ukrainian Carpathians. In: Problems of stratigraphy of Phanerozoic of Ukraine: Coll. Sci. works of IGS of NAS of Ukraine. Kyiv, pp. 105-109 (in Ukrainian).

Andreyeva-Grigorovich A.S., Ivanik M.M., Maslun N.V. et al., 2013. Paleobasin Maikop and its age analogs (stratigraphy, evolution of biota, sedimentation). The stratigraphy of sedimentary rocks of the Upper Proterozoic and Phanerozoic: Proceedings of the Intern. Sci. conf. (Kyiv, September 23-26, 2013). Kyiv, pp. 13-15 (in Ukrainian).

Beniamovski, V.N., 2001. Justification of detailed stratigraphic scheme of the Lower Paleogene of CrimeanCaucasus region. In: Ways of detalization of stratigraphic schemes and paleogeographic reconstructions. Moscow: GEOS, pp. 210-223 (in Russian).

Bugrova E.M., 2001. The stratigraphic and geographic distribution of Upper Eocene foraminifera on the northern edge of the Tethys basin. Stratigraphy, geological correlation (Stratigrafiya. Geologicheskaya correlatsiya), vol. 9, № 2, pp. 92-104 (in Russian).

Bukry D., 1973. Low-latitude coccolith biostratigraphic zonation. Initial Reports of the DSDP, vol. 15. pp. 685-703 (in English).

Gozhyk P.F., Maslun N.V., Ivanik M.M. et al., 2015. Stratigraphy, correlation of the Maikopian deposits of the Carpathian-Black Sea segment of the Paratethys. Geology and Mineral Resources of World Ocean (Geologija $i$ poleznye iskopaemye Mirovogo okeana), № 3 (41), pp. 528 (in Ukrainian).
NAS of Ukraine), Z.Ya. Voitsitsky (Ukrgeophisics), doctor of geological scienses O.M. Hnylko (Institute of Geology and Geochemistry of Combustible Mineral NAS of Ukraine), candidate of geological scienses D.V. Machalsky, V.O. Vashenko (DP NAK "Nadra Ukraine" Zahidukrgeologiya), but olso the editors of the Journal for their comments and corrections and S.D. Aksjom for article layout creation..

Андреева-Григорович А.С. Зональная шкала палеогена юга СССР по наннопланктону/ А.С. АндрееваГригорович, Н.Г. Музылёв, И.П. Табачникова // Зональная стратиграфия фанерозоя СССР. - М.: Недра, 1991. - C. $134-135$.

Андреева-Григорович А.С. Атлас диноцист палеогена Украины, России и сопредельных стран / А.С. Андреева-Григорович, Н.И. Запорожец, Т.В. Шевченко и др. Киев: Наук. думка, 2011. - 224 с.

Андрєєва-Григорович А.С. Регіояруси палеогену Українських Карпат / А.С. Андрєєва-Григорович, М.М. Іванік, Н.В. Маслун та ін. // Проблеми стратиграфії фанерозою України: Зб. наук. пр. ІГН НАН України. Київ, 2004. - С. 105-109.

Андрєєва-Григорович А.С. Майкопський палеобасейн та його вікові аналоги (стратиграфія, еволюція біоти, осадконакопичення) / А.С. Андрєєва-Григорович, М.М. Іванік, Н.В. Маслун та ін. // Стратиграфия осадочных образований верхнего протерозоя и фанерозоя: Материалы Междунар. науч. конф. (Киев, 23-26 сент. 2013 г.). - Киев, 2013. - С. 13-15.

Беньямовский В.Н. Обоснование детальной стратиграфической схемы нижнего палеогена КрымскоКавказской области / В.Н. Беньямовский // Пути детализации стратиграфических схем и палеогеографические реконструкции. - Москва: ГЕОС, 2001. - С. 210223.

Бугрова Э.М. Стратиграфическое и географическое распространение верхнеэоценовых фораминифер на северной окраине бассейна Тетис. / Э.М. Бугрова // Стратиграфия. Геол. корреляция. - 2001. - Т. 9, -№ 2. - С. 92-104.

Bukry D., 1973. Low-latitude coccolith biostratigraphic zonation. Initial Reports of the DSDP, vol. 15. pp. 685-703 (in English).

Гожик П.Ф. Стратиграфія, кореляція майкопських відкладів Карпатсько-Чорноморського сегменту Паратетису / П.Ф. Гожик, Н.В. Маслун, М.М. Іванік, А.С. Андрєєва-Григорович та ін. // Геология и полезные ископаемые Мирового океану. - 2015. - № 3 (41). C. 5-28. 
Gozhyk P.F., Maslun N.V., Ivanik Ye.M., Kliushyna G.V., 2011. Stratigraphy of Paleogene, Neogene and Quaternary deposits in the Black Sea oil-gas province of Ukraine. Stratigraphy and sedimentology of oil-gas basins (Stratihrafiya i sedimentologiya neftegazonosnykh basseynov), No 2, pp. 15-31 (in English).

Gozhyk P.F., Maslun N.V., Plotnikova L.F. et al., 2006. Stratigraphy of Mesozoic-Cenozoic sediments of the north-western Black Sea shelf. Kyiv, 171 p. (in Ukrainian).

Gruzman A.D., 1983. Foraminifera and stratigraphy of the Oligocene and Lower Miocene of Ukrainian Carpathians. Extended abstract of candidate's thesis in geol.-mineral. sci., Kyiv, 24 p. (in Russian).

Hnylko S., Hnylko O., 2016. Foraminiferal stratigraphy and palaeobathymetry of Paleocene-lowermost Oligocene deposits (Vezhany and Monastyrets nappes, Ukrainian Carpathians). Geological Quarterly, vol. 60 (1), pp. 75-103 (in English).

Ivanik M.M., Maslun N.V., 1977. Siliceous microorganisms and their application for the Paleogene biostratigraphy of the Forecarpathians. Kyiv: Naukova Dumka, 120 p. (in Russian).

Justification of the stratigraphic units of the MesozoicCenozoic of Ukraine based on microfauna, 1975 (Ed. V.Ya. Didkovskiy). Kiev: Naukova Dumka, 231 p. (in Russian).

Kaptarenko-Chernousova O.K., 1958. Zonal subdivision of deposits of Kiev Stage. Reports of the USSR Academy of Sciences (Doklady AN USSR), No 7, pp. 772-775 (in Russian).

Krasheninnikov V.A., Basov I.A., 2007. Stratigraphy of Stratigraphy of Paleogene deposits of the World Ocean and their correlation with continental sections. Moscow: The scientific world (Nauchnuy mir), 2007, 316 p. (Proceedings of GIN RAN; Iss. 583) (in Russian).

Kraeva Ye.Ya., Yartseva M.V., 1973. Characteristics of the Oligocene Planktonic Foraminifera from the Northern Black Sea Region. Ibid (Dopovidi AN URSR), Ser. B, No 8, pp. 693-696 (in Ukrainian).

Krayeva E.Y., Maslun N.V., 1984. The biostratigraphic value of benthic foraminifera for the subdivision and correlation of Paleogene deposits of Ukraine. Geological Journal (Heolohichnyi zhurnal), No 4 (217), pp. 107-112 (in Russian).

Martini E., 1971. Standard Tertiary and Quaternary calcareous nannoplankton zonation. In: Farinacci, A. (Ed.), Proceedings of the II Planktonic Conference, Roma, 1970, Edizioni. Technoscienca, vol. 2, pp. 739-785 (in English).

Maslun N.V. Inozemtsev Yu.I., Orovetskiy Yu.Yu., 1989. Lower Cenozoic deposits of the Crimean Black Sea continental slope (results of 37 trip NIS "Akademik
Gozhyk P.F. Stratigraphy of Paleogene, Neogene and Quaternary deposits in the Black Sea oil-gas province of Ukraine. / P.F. Gozhyk, N.V. Maslun, Ye.M. Ivanik, G.V. Kliushyna // Стратиграфия и седиментология нефтегазоносных бассейнов. - 2011. - № 2. - С. 15-31.

Гожик П.Ф. Стратиграфія мезо-кайнозойських відкладів північно-західного шельфу Чорного моря. / П.Ф. Гожик, Н.В. Маслун, Л.Ф. Плотнікова та ін. -Київ, 2006. $171 \mathrm{c}$.

Грузман А.Д. Фораминиферы и стратиграфия олигоцена и нижнего миоцена Украинских Карпат: автореф. дис. ... канд. геол.-минерал. наук. - Киев, 1983. - 24 с.

Hnylko S. Foraminiferal stratigraphy and palaeobathymetry of Paleocene-lowermost Oligocene deposits (Vezhany and Monastyrets nappes, Ukrainian Carpathians) / S. Hnylko, O. Hnylko // Geological Quarterly. - 2016. Vol. 60 (1). - P. 75-103.

Иваник М.М. Кремнистые микроорганизмы и их использование для расчленения палеогеновых отложений Предкарпатья / М.М. Иваник, Н.В. Маслун Киев: Наук. думка, 1977. - 120 с.

Обоснование стратиграфических подразделений мезокайнозоя Украины по микрофауне / под ред. В.Я. Дидковского. - Киев: Наук. думка, 1975. - 231 с.

Каптаренко-Черноусова О.К. Зональное расчленение отложений киевского яруса / О.К. КаптаренкоЧерноусова // Докл. АН УССР. -1958. - № 7. - С. 772775.

Крашенинников В.А. Стратиграфия палеогеновых отложений Мирового океана и корреляция с разрезами на континентах / В.А. Крашенинников, И.А. Басов. - М.: Науч. мир, 2007. - 316 с. - (Тр. ГИН РАН; Вып. 583).

Краєва Є.Я. Характеристика планктонних форамініфер олігоцену Північного Причорномор'я / Є.Я. Краєва, М.В. Ярцева // Доп. АН УРСР. Сер. Б. - 1973. - № 8. C. 693-696.

Краева Е.Я. Значение бентосных фораминифер для расчленения и корреляции палеогеновых отложений Украины / Е.Я. Краева, Н.В. Маслун // Геол. журн. 1984. - T. 44. -№ 4. - С. 107-112.

Martini E. Standard Tertiary and Quaternary calcareous nannoplankton zonation / E. Martini // In: Farinacci, A. (Ed.), Proceedings of the II Planktonic Conference, Roma, 1970, Edizioni. Technoscienca. - 1971. - Vol. 2. - P. 739 785.

Маслун Н.В. Нижнекайнозойские отложения Крымского континентального склона Черного моря (результаты 37-го рейса НИС "Академик Вернадский»)/ 
Vernadskiy"). Kiev, 36 p. (Preprint / Ukrainian Academy of Sciences. Institute of Geological Sciences; 89-13) (in Russian).

Maslun N.V., Mintuzova L.G., Hnylko S.R., 2015. Detailed stratification and correlation of foraminifera paleogene deposits of Ukraine. Geological Journal (Heolohichnyi zhurnal), Kyiv, No 4 (353), pp. 31-49 (in English).

Mintuzova L.G., 2008. Detailed biostratigraphy of Palaeocene-Eocene sediments of the Kerch Peninsula and their correlation with the surrounding regions of the Crimea. In: Biostratigraphy in generating Phanerozoic stratigraphic schemes of Ukraine: Coll. Sci. works of IGS of NAS of Ukraine, Kyiv, pp. 150-158 (in Ukrainian).

Myatlyuk E.V., 1970. Foraminifera from flysch sediments of the Eastern Carpathians (Cretaceous - Paleogene). Leningrad: Nedra, 360 p. (in Russian).

Okada H., Bukry D., 1980. Supplementary modification and introduction of code numbers to the low-latitude coccolith biostratigraphic zonation. Marine Micropaleontology, vol. 5, No 3, pp. 321-325 (in English).

Quillévéré F., Aubry M.-P., Norris R.D., Berggren W.A., 2002. Paleocene oceanography of the eastern subtropical Indian Ocean. An integrated magnetobiostratigraphic and stable isotope study of ODP Hole $761 \mathrm{~B}$ (Wombat Plateau). Paleogeography, Paleoclimatology, Paleoecology, 184, pp. 371-405 (in English).

Romaniv A.M., 1991. Calcareous nannofossils of the Cretaceous and Paleogene sediments of the Ukrainian Carpathians. Kyiv: Naukova Dumka, 148 p. (in Russian).

Ry'abokon T.S., 2014. Paleogene biostratigraphy of Southern Ukraine based on planktonic foraminifera. Problems of Phanerozoic geology of Ukraine: Proceeding of the V Ukrainian Scientific Conference (Lviv, 8-10 October 2014). Lviv, pp. 101-104 (in Ukrainian).

Subbotina N.N., 1960. Pelagic foraminifera of Paleogene deposits of south of the USSR. In: Paleogene deposits of south of the European part of the USSR. Moscow: Izdatelstvo AN SSSR. pp. 24-38 (in Russian).

Suprun I.S., 2017. Calcareous nannofossil biozonation of the Paleocene sediments of the Carpathian-Black Sea segment of Tethys. 40 years for the Paleontological Society of Ukraine: Proceedings of the XXXVIII session of the Paleontological Society of Ukraine (Kaniv, May 23-26, 2017). Kyiv, pp. 109-110 (in Ukrainian).

Tutkovsky P.A., 1887. Foraminifera of the Tertiary and Cretaceous sediments of Kiev. Article 1. 3KOE, vol. VIII, No 2, pp. 345-360, (tab. III-VII. Ref.: Bull. Soc., Belg. Geol., Hydrol. Et Paleont., t, I, proc, verb., p. 195).

Vyalov O.S., Gavura S.P., Danysh V.V. et al., 1988. Stratotypes of Cretaceous and Paleogene sediments of the Ukrainian Carpathians. Kyiv: Naukova Dumka, 204 p. (in Russian).
Н.В. Маслун, Ю.И. Иноземцев, Ю.Ю. Оровецкий - Киев, 1989. - 36 с. (Препр. / АН УССР. Ин-т геол. наук; 89-13).

Maslun N.V. Detailed stratification and correlation of foraminifera paleogene deposits of Ukraine / N.V. Maslun, L.G. Mintuzova, S.R. Hnylko // Геол. журн. - 2015. - №4 (353). - C. 31-49.

Мінтузова Л.Г. Детальна стратифікація палеоцен-еоценових відкладів Керченського півострова та їх кореляція з прилеглими районами Криму / Л.Г. Мінтузова // Біостратиграфічні основи побудови стратиграфічних схем фанерозою України: Зб. наук. пр. ІГН НАН України. - Київ, 2008. - С. 150-158.

Мятлюк Е.В. Фораминиферы флишевых отложений Восточных Карпат (мел - палеоген) / Е.В. Мятлюк Ленинград: Недра, 1970. - 360 с.

Okada H. Supplementary modification and introduction of code numbers to the low-latitude coccolith biostratigraphic zonation / H. Okada, D. Bukry // Marine Micropaleontology. - 1980. - Vol. 5. -№ 3. - P. 321-325.

Quillévéré F. Paleocene oceanography of the eastern subtropical Indian Ocean. An integrated magnetobiostratigraphic and stable isotope study of ODP Hole 761 B (Wombat Plateau) / F. Quillévéré, M.-P. Aubry, R.D. Norris, W.A. Berggren // Paleogeography, Paleoclimatology, Paleoecology 184. - 2002. - P. 371-405.

Романив А.М. Известковый наннопланктон меловых и палеогеновых отложений Украинских Карпат / А.М. Романив - Киев: Наук. думка, 1991. -148 с.

Рябоконь Т.С. Про біостратиграфію палеогену Південної України за планктонними форамініферами / Т.С. Рябоконь // Проблеми геології фанерозою України: Матеріали V всеукр. наук. конф. (8-10 жовтня 2014, Львів). - Львів, 2014. - С. 101-104.

Субботина Н.Н. Пелагические фораминиферы палеогеновых отложений юга СССР / Н.Н. Субботина // Палеогеновые отложения юга европейской части СССР. - Москва: Изд-во АН СССР, 1960. - С. 24-38.

Супрун І.С. Зонування за нанопланктоном палеоценових відкладів Карпатсько-Чорноморського сегменту Тетісу / І.С. Супрун // 40 років Палеонтологічному товариству України: Матеріали XXXVIII сесії Палеонтологічного товариства України (Канів, 23-26 травня 2017 р.). - Київ, 2017. - С. 109-110.

Тутковский П.А. Фораминиферы из третичных и меловых отложений Киева. Статья 1. ЗКОЕ / П.А. Тутковский - т. VIII. - вып. 2. - С. 345-360, (табл. III-VII. Реф.: Bull. Soc., Belg. Geol., Hydrol. Et Paleont., 1887, t, I, proc, verb., p. 195).

Вялов О.С. Стратотипы меловых и палеогеновых отложений Украинских Карпат / О.С. Вялов, С.П. Гавура, В.В. Даныш и др. - Киев: Наук. думка, 1988. - 204 с. 
Wade B.S., Pearson P.N., Berggren A.W., Pдlike H., 2011. Review and revision of Cenozoic tropical planktonic foraminiferal biostratigraphy and calibration to the geomagnetic polarity and astronomical time scale. EarthScience Reviews, 104, pp. 111-142 (in English).

Waga D.D., 2007. Paleocene-Eocene calcareous nannofossils of the southern periphery of the East European Platform. Extended abstract of candidate's thesis in geol.mineral. sci., Kyiv, 28 p. (in Ukrainian).

Waga D.D., Andreeva-Grigorovich A.S., Maslun N.V., 2010. Calcareous nannofossil biostratigraphy of the Paleocene sediments of the Odessa Gas Field (NW Black Sea). Geobios, 43, pp. 33-43 (in English).

Zhabina N.M., Mintuzova L.G., 2000. The model of the geological structure of south-eastern Crimea. Geology and geochemistry of fossil fuels (Geologiya i geokhimiya goryuchykh kopalyn), No 1, pp. 25-35(in Ukrainian).

Zernetsky B.F., Lj'ulyeva S.A., 1990. Zonal biostratigraphy of Eocene of the European part of the USSR. Kyiv: Naukova Dumka, 96 p. (in Russian).

Manuscript received 2 June 2017; revision accepted 27 October 2017
Wade B.S. Review and revision of Cenozoic tropical planktonic foraminiferal biostratigraphy and calibration to the geomagnetic polarity and astronomical time scale / B.S. Wade, P.N. Pearson, A.W. Berggren, H. Pдlike //EarthScience Reviews. - 2011. - № 104. -P. 111-142.

Вага Д.Д. Нанопланктон палеоцен-еоцену Південної периферії Східно-Європейської платформи: автореф. дис. ... канд. геол. наук. - Київ, 2007. - 28 с.

Waga D.D. Calcareous nannofossil biostratigraphy of the Paleocene sediments of the Odessa Gas Field (NW Black Sea) / D.D. Waga, A.S. Andreeva-Grigorovich, N.V. Maslun // Geobios, 43 - 2010. - P. 33-43.

Жабіна Н.М., Мінтузова Л.Г. Модель геологічної будови південно-східного Криму / Н.М. Жабіна, Л.Г. Мінтузова // Геологія і геохімія горючих копалин. - 2000. - № 1. - C. 25-35.

Зернецкий Б.Ф. Зональная биостратиграфия эоцена европейской части СССР / Б.Ф. Зернецкий, С.А. Люльева - Киев: Наук. думка, 1990. - 96 с.

Інститут геологічних наук НАН України Київ, Україна

\section{ПЛАНКТОННАЯ БИОСТРАТИГРАФИЯ (ФОРАМИНИФЕРЫ, НАННОПЛАНКТОН, ДИНОЦИСТЫ) ПАЛЕОГЕНОВЫХ ОТЛОЖЕНИЙ НЕФТЕГАЗОНОСНЫХ ПРОВИНЦИЙ УКРАИНЫ}

А.С. Андреева-Григорович, Н.В.Маслун, М.М. Иваник, Д.Д. Вага, Н.Н. Жабина, С.Р. Гнилко., И.С. Супрун, Л.Г. Минтузова

На территории Украины перспективными нефтегазоносными регионами являются Карпато-Черноморский сегмент Тетиса и Южные склоны Восточно-Европейской платформы. Авторами лично проведены исследования планктонных микрофоссилий из многочисленных разрезов палеогеновых отложений в обнажениях и раскрытых поисково-разведочными и параметрическими скважинами. Обработана значительная информация по пространственно-временному распределению фораминифер, наннопланктона и диноцист в палеогене, на основании чего установлены закономерности и особенности стратиграфической приуроченности планктонных ассоциаций ископаемых остатков в палеогеновых разрезах, их цикличность в формационных комплексах. Изложена специфика биозонального распределения по установленным корреляционным уровням. В результате комплексных исследований обосновано биозональное деление палеогеновых отложений Украины, выполнена межрегиональная корреляция разнофациальных палеогеновых раз- резов и корреляция с международной стратиграфической шкалой.

Ключевые слова: фораминиферы, наннопланктон, диноцисты, биозональная шкала, корреляция, палеоген, Украина. 